\title{
УДК: 640.4-028.42:338.48:330.3
}

Мізюк Б. М.,

mizjuk.bohdan@gmail.com, ORCID ID: 0000-0002-6917-6351,

Researcher ID: F-9090-2019,

д.е.н., проф., завідувач кафедри туризму та готельно-ресторанної справи, Львівський торговельноекономічний університет, м. Львів

\section{СТРАТЕГІЧНИЙ РОЗВИТОК КОРПОРАТИВНИХ СТРУКТУР У ТУРИСТИЧНО-ГОТЕЛЬНОМУ БІЗНЕСІ}

\begin{abstract}
Анотація. Питання появи та становлення корпоративних відносин займають важливе місие в роботах вітчизняних науковців у всіх сферах економічної науки. Однак процеси, щзо відбувається в стратегічному, готельному та ресторанному бізнесі, є досить специфічними $і$ потребують глибокого вивчення. У статті розглянуто теоретичні аспекти стратегічного управління в готельному та ресторанному бізнесі. Корпоративний сегмент туристичного і готельно-ресторанного бізнесу на даний час представлений у вигляді більшості підприємств, які діють у формі акціонерних товариств або у вигляді об 'єднання підприємств і меншою мірою представлений транснаціональними компаніями, які діють у формі франчайзингових мереж та контрактного управління. В результаті аналізу та узагальнення праць вітчизняних та зарубіжних учених проведено дослідження витоків системи стратегічного управління. Визначено сутність та особливості впровадження стратегічного управління туристичним та готельним бізнесом. Встановлено переваги та труднощі розробки стратегій. Зазначено рівень впровадження запропонованих стратегій у діяльність туристичних та готельних підприємств. Запропоновано передумови дослідження можливостей $і$ перспектив впровадження стратегічного типу управління в туристичному $і$ готельно-ресторанному бізнесі. Обтрунтовано доиільність застосування різних стратегій у туристичному бізнесі, визначено можливі напрями їх реалізації та очікувані результати. Зроблено висновок, ше впровадження і використання стратегічного типу управління сприятиме подальшому розвитку готельно-ресторанний бізнесу в Україні. Це дасть можливість використати специифічні особливості наявного туристичного потенціалу Украйни до залучення в міжнародний туристичний та готельно-ресторанний бізнес і тим самим прискорити вихід на передові економічні позиції.
\end{abstract}

Ключові слова: туризм, стратегічне управління, готельно-ресторанний бізнес, туристичні підприємства, корпоративні структури.

Mizyuk B. M.,

mizjuk.bohdan@gmail.com, ORCID ID: 0000-0002-6917-6351,

Researcher ID: F-9090-2019,

Doctor of Economics, Professor, Head of the Department of Tourism and Hotel\& Restaurant Business, Lviv University of Trade and Economics, Lviv

\section{STRATEGIC DEVELOPMENT OF CORPORATE STRUCTURES IN THE TOURISM AND HOTEL BUSINESS}

\begin{abstract}
Issues of emergence and formation of corporate relations occupy an important place in the works of domestic scientists in all areas of economic studies. However, the processes that take place in the strategic level of hotel and restaurant business are quite specific and require in-depth study. The article considers the theoretical aspects of strategic management in the hotel and restaurant business. The corporate segment of the tourism and hotel\&restaurant business is currently represented mostly in the form of enterprises operating as joint stock companies or as an association of enterprises and to a lesser extent as multinational companies operating in the form of franchising networks or contracted management. As a result of the analysis and generalization of works of domestic and foreign scientists the research of beginnings of strategic management system is carried out. The essence and features of introduction of strategic management of tourist and hotel business are defined. The advantages and difficulties of strategies development are identified. The level of implementation of the proposed strategies in the activities of tourism and hotel enterprises is indicated. Prerequisites for the study of opportunities and prospects for the introduction of a strategic type of management in the tourism and hotel\&restaurant business are proposed. The expediency of application of various strategies in the tourism business is substantiated as well as possible directions of their implementation and expected results are defined. It is concluded that the introduction and use of a strategic type of management will contribute to the further development of the hotel and restaurant business in Ukraine. This will make possible to use the specific features of the existing tourism potential of Ukraine for engagement in international tourism and hotel\&restaurant business and thus accelerate access to advanced economic positions.
\end{abstract}

Key words: tourism, strategic management, hotel and restaurant business, tourist enterprises, corporate structures.

JEL Classification: L10, L12

DOI: https://doi.org/10.36477/2522-1205-2020-61-08 
Постановка проблеми. Туризм, готельний та ресторанний бізнес $є$ важливими секторами економіки, що суттєво впливають на економічносоціальне становище країни. Від їхнього розвитку залежить багато складових як економічного, так i соціального становища різних верств населення. Труднощі та складності становлення цього бізнесу мають багатоаспектний характер. Незважаючи на них, виразною тенденцією туристичного, готельного та ресторанного бізнесу є посилення процесів інтеграції та глобалізації, що приводить до утворення в даній сфері гостинності корпоративних утворень. В цьому зв'язку виникає необхідність аналізу специфіки їх функціонування та розвитку. Це важливо як для визначення чинників конкурентоспроможності, так і формування стратегій подальшого підвищення ефективності їх діяльності.

Питання появи та становлення корпоративних відносин займають важливе місце в роботах вітчизняних науковців у всіх сферах економічної науки. Однак процеси, що відбувається в стратегічному, готельному та ресторанному бізнесі, є досить специфічними і потребують глибокого вивчення.

Аналіз останніх досліджень і публікацій. До розкриття питань із цієї тематики слід віднести праці Борущака М. А. [2], М. П. Мальської [3], С. В. Мельниченка [5], та інших. У роботах названих вчених розглядаються інтеграційні процеси в управлінні підприємствами туристичного та готельного бізнесу, транснаціонального туристичного ринку, ведення малого бізнесу в системі корпоративних відносин.

Постановка завдання. Постійні зміни зовнішнього середовища та умов ведення цього специфічного виду бізнесу потребують постійних досліджень у встановленні та розвитку корпоративних відносин в царині туристичного та готельно-ресторанного бізнесу.

Важливим на даному етапі $\epsilon$ проведення аналізу сучасного стану становлення корпоративних відносин та узагальнення базисних засад подальшого їх розвитку та застосування основ стратегічного управління бізнес-процесами при здійсненні туристичної та готельно-ресторанної діяльності корпоративних утворень.

Виклад основного матеріалу дослідження. Корпоративне управління $є$ однією 3 найпоширеніших форм організації здійснення бізнеспроцесів у ринкових економіках розвинутих країн. Корпоративна стратегія визначає загальний напрямок діяльності корпорації, що реалізується вищим керівництвом корпоративного утворення і передбачає три основні завдання:

1) сформувати, фактично вибрати головний напрямок діяльності корпорації і іiі стратегічних одиниць бізнесу (СОБ);

2) визначити конкретну роль кожної СОБ ї їі структурних одиниць у реалізації корпоративної стратегіі;

3) встановити розміри і способи розподілу ресурсів між СОБ.

У мультибізнесових структурах, до яких відносяться i корпорації, корпоративна стратегія базується на бізнес-стратегіях кожної СОБ, ефективне виконання яких спрямоване на досягнення цілей, поставлених у корпоративній стратегії. В однобізнесових структурах власне бізнес-стратегія може розглядатись як корпоративна. В цьому випадку корпоративна стратегія може виступати як одна 3 таких базових стратегій: а) стратегія зростання (розвитку); б) стратегія стабілізації (обмеженого зростання); в) стратегія виживання (скорочення); г) стратегія у вигляді комбінації трьох попередніх.

Стратегія зростання (розвитку) обирається у випадку, коли корпорація або СОБ мають прагнення і відповідні можливості, а також власні сильні сторони для нарощування обсягів реалізації своїх продуктів. Як правило, це доцільно при завоюванні нових сегментів ринку та підвищенні якості використання нових інноваційних продуктів. Дана стратегія $\epsilon$ ефективною для туристичного та готельноресторанного бізнесу, що динамічно розвивається і ефективно використовує інноваційні продукти.

Системи здійснення такої стратегії можуть бути наступними: 1) поглинання (придбання) конкуруючих (і не тільки) фірм через придбання контрольного пакета акцій; 2) злиття-об'єднання на однакових (рівних) засадах із іншими бізнесструктурами; 3) створення спільного підприємства (СП) на основі об'єднання частини капіталу з метою реалізації перспективного і привабливого проекту.

Стратегію стабілізації (обмеженого зростання) доцільно використовувати корпораціям туристичного i готельно-ресторанного бізнесу, які ще домінують на даному ринку, мають стабільний обсяг реалізації своєї продукції і стабільний прибуток і хочуть підтримати існуючий стан якомога довший період часу. Ця стратегія характерна для стадії зрілості життєвого циклу (ЖЦ) корпорації і його продукту.

Стратегія виживання (скорочення) застосовується корпораціями, в тому числі і у сфері туристичного та готельно-ресторанного бізнесу, в умовах економічної кризи, нестабільності, високої інфляції або коли продукція досягла стану насиченості і спаду ЖЦ. Ця стратегія полягає в пошуку варіантів пристосування до важких ринкових умов. До неї варто вдатися, коли проявляється чітка тенденція спаду фінансово-економічних показників, 3'являються загрози подальшого існування самої бізнес-структури. Тоді доцільно скористатися стратегією розвитку - коли корпорація або СОБ працює неефективно, але ще не досягла критичної точки і $€$ шанс покращити свій стан. В цьому випадку відмовляються від нерентабельних товарів та послуг, скорочення зайвої робочої сили, від неефективних каналів розподілу ресурсів (вкладень) тощо. В умовах кризи використовується також і стратегія відокремлення. В цьому випадку відмовляються від нерентабельного бізнесу (по можливості його продають) i в крайньому випадку використовують стратегію ліквідації, коли корпорація або СОБ досягла критичної точки -банкротства, - тоді вони ліквідуються, а активи продаються. 


\section{Herald of Lviv University of Trade and Economics. Economic Sciences. № 61, 2020}

Важливе місце при використанні стратегічного управління відводиться виробленню стратегічних альтернатив. Вони виступають як можливі варіанти розвитку корпорації чи СОБ у межах кожної 3 трьох базових корпоративних стратегій, а саме: зростання, стабілізації, скорочення. В межах стратегії зростання можна виділити: 1) стратегію інтенсифікації; 2) стратегію диверсифікації; 3) стратегію інтеграції; 4) стратегію інновацій. В межах стратегії стабілізації (обмеженого зростання) виокремлюють: 1) стратегію економії витрат; 2) стратегію "зростання врожаю"; 3) адаптації до умов зовнішнього середовища; 4) збереження технічнонаукового і кадрового потенціалу. В межах стратегії виживання (скорочення) прийнято застосовувати стратегії: 1) організаційної санації; 2) економічної і фінансової санації; 3) маркетингової санації; 4) соціальної санації; 5) ліквідації бізнесу. Слід відзначити, що відповідність стратегічних альтернатив базовій стратегії не потрібно сприймати як незмінну. Альтернативи можуть "перехрещуватися”. Кожна з базових корпоративних стратегій може мати безліч альтернативних варіантів реалізації. В свою чергу, стратегічні альтернативи повинні реалізовуватися через набір заходів. При цьому по кожному заходу доцільно визначити затрати на їх виконання і порахувати очікуваний економічний ефект.

Передумовами дослідження можливостей i перспектив впровадження стратегічного типу в туристичний і готельно-ресторанний бізнес можна вважати:

1) проникнення міжнародних туристичних, готельних і ресторанних мереж на ринок гостинності нашої держави;

2) інтеграцію вітчизняних i готельноресторанних бізнес-структур у світове економічне співтовариство i, відповідно, повну зміну пріоритетів в їх інвестиційній політиці;

3) нагальну необхідність та важливість формування інвестиційної привабливості ринку послуг туристичного і готельно-ресторанного обслуговування.

Корпоративний сегмент туристичного і готельно-ресторанного бізнесу на даний час представлений у вигляді більшості підприємств, які діють у формі акціонерних товариств або у вигляді об'єднання підприємств і меншою мірою представлений транснаціональними компаніями, які діють у формі франчайзингових мереж та контрактного управління.

До характерних рис, що відображають процеси функціонування і розвитку корпорацій туристичного і готельно-ресторанного бізнесу, можна віднести наступне [1, 4]:

1. Особливості створення корпоративних структур на вітчизняному ринку, на відміну від зарубіжних туристичних і готельних корпорацій, полягають у тому, що вітчизняні корпоративні структури створювалися шляхом приватизації державних та комунальних підприємств. Певні винятки можна зробити для ресторанних закладів.
2. Чинниками корпоратизації туристичного i готельно-ресторанного бізнесу можна вважати наступне: 1) структуризація ринку послуг; 2) особливості споживання послуг; 3) інноваційність технологічних процесів; 4) територіальна розташованість; 5) взаємозв'язаність виробничо-технологічних процесів; 6) інвестиційна та інноваційна активність учасників ринку туристичних та готельно-ресторанних послуг.

3. Переважною характерною рисою сучасного ринку туристичних і готельно-ресторанних послуг $\epsilon$ поява моделі мережевих відносин, пов'язана $з$ наявністю нових бізнес-груп, що контролюються певною (доволі клановою) групою домінуючих партнерів, у яких основним інструментом контролю є система перехресного володіння, що пов'язане $з$ практичною відсутністю міноритарних акціонерів і високою питомою вагою найбільшого власника в структурі капіталу корпорації.

4. Реєстрація великих корпорацій туристичного і готельно-ресторанного типу в офшорних зонах, де дохід не оподатковується взагалі або оподатковується за низькими ставками, приводить до непрозорості корпоративних відносин і ускладнює встановлення кінцевих бенефіціонерів корпорацій.

5. Низький розвиток фондового ринку негативно впливає на джерела залучення капіталу до корпоративного сегмента туристичного і готельноресторанного бізнесу. Тому корпорації цього сегмента позбавлені можливості доступу до більш дешевих джерел інвестицій. Випуск цінних паперів (акцій, облігацій) для вітчизняних корпорацій $є$ не характерним для національного туристичного та готельно-ресторанного бізнесу.

Кризові явища у вітчизняній економіці блокують процеси входження на ринок туристичного та готельно-ресторанного бізнесу міжнародних мереж. Серед причин низького рівня розвитку слід відзначити: 1) високий ризик інвестування; 2) неоднозначність та відсутність фінансових можливостей залучення коштів 3 фондового ринку; 3) брак кваліфікованих кадрів у корпоративному управлінні туристичним і готельно-ресторанним бізнесом; 4) недостатня державна підтримка.

Разом 3 тим, стратегічний підхід до розвитку корпорацій у вітчизняній сфері туристичних і готельно-ресторанних послуг свідчить, що його застосування потребує розвитку відповідних мереж корпоративного спрямування. Це дозволить отримати кращі знання особливостей вітчизняного ринку сфери гостинності, глибше зрозуміти споживачів у отриманні якісних послуг, налагодити ефективні партнерські зв'язки 3 постачальниками та іншими контрагентами і сформувати позитивний імідж відповідних корпорацій. Це дозволить побудувати вітчизняну модель у туристичному та готельно-ресторанному бізнесі, яка б давала можливість адаптуватися до міжнародних правил та умов ведення доволі складного виду бізнесу і у перспективі отримати позитивні наслідки, зокрема: 1) формувати сприятливий інвестиційний клімат;

2) підвищити ефективність використання капіталу;

3) формувати мультиплікаційний ефект впливу на 
суміжні сфери бізнесу; 4) можливість залучати значний інвестиційний капітал; 5) використовувати можливості диверсифікації.

Висновки i перспективи подальших досліджень у даному напрямі. Сучасний період розвитку ринкових відносин у здійсненні туристичного і готельно-ресторанного бізнесу характеризується яскравими передумовами динамічного руху капіталів через посередництво туристичного і готельно-ресторанного бізнесу. Останнє потребує активного включення стратегічних підходів до розвитку туристичного i готельно-ресторанного бізнесу; особливо це стосується нових підходів до управління розвитком корпоративних відносин, особливо в сфері туристичного і готельноресторанного господарства. Саме впровадження i використання стратегічного типу управління сприятиме подальшому розвитку цієї сфери бізнесу. Це дасть можливість використати специфічні особливості наявного туристичного потенціалу України до залучення в міжнародний туристичний та готельноресторанний бізнес і тим самим прискорити вихід на передові економічні позиції. Розуміння значущості даного процесу сприятиме розвитку сфери гостинності, сприятиме адаптації до стандартів міжнародного рівня.

\section{ЛIТЕРАТУРА}

1. Ансофф И. Новая корпоративная стратегия / И. Ансофф / [Пер. с английского С. Жильцова; под общ. ред. Ю. Н. Каптуревского]. - СПб. : Питер, 1999. - 416 с.

2. Борущак М. А. Проблеми формування стратегії розвитку туристичних регіонів : монографія / М. А. Борущак. - Львів : ІРД НАН України, 2006. $288 \mathrm{c}$.
3. Мальська М. П. Планування туристичної діяльності : підручник / М. П. Мальська, О. Ю. Бордун. - К. : Знання, 2010. - 310 с.

4. Нездоймінов С. Концептуальні засади формування стратегії диверсифікації на підприємствах туристичного бізнесу / С. Нездоймінов, Н. Андрєєва // Вісник економічної науки України. 2013. - № 2. - С. 108-112.

5. Стратегічний розвиток туристичного бізнесу : монографія / [Т. І. Ткаченко, С. В. Мельниченко, М. Г. Бойко та ін. ; за заг. ред. А. А. Мазаракі]. К. : Київ. нац. торг.-екон. ун-т, 2010. - 648 с.

\section{REFERENCES}

1. Ansoff Y. (1999), Novaya korporatyvnaya stratehyya, per. s anhlyyskoho S. Zhyl'tsova; pod obshch. red. YU. N. Kapturevskoho, Pyter, SPb., 416 s.

2. Borushchak, M. A. (2006), Problemy formuvannya stratehiyi rozvytku turystychnykh rehioniv : monohrafiya, IRD NAN Ukrayiny, L'viv, 288 s.

3. Mal's'ka, M. P. and Bordun, O. YU. (2010), Planuvannya turystychnoyi diyal'nosti : pidruchnyk, Znannya, K., $310 \mathrm{~s}$.

4. Nezdoyminov S. and Andryeyeva N. (2013), Kontseptual'ni zasady formuvannya stratehiyi dyversyfikatsiyi na pidpryyemstvakh turystychnoho biznesu, Visnyk ekonomichnoyi nauky Ukrayiny, № 2, s. 108112.

5. Stratehichnyj rozvytok turystychnoho biznesu : monohrafiia, T. I. Tkachenko, S. V. Mel'nychenko, M. H. Bojko ta in. ; za zah. red. A. A. Mazaraki (2010), Kyiv. nats. torh.-ekon. un-t, K., 648 s.

Стаття надійшла до редакиіï 11 листопада $2020 \mathrm{p}$. 